RESEARCH PAPER

\title{
Complicity in contraband: British American Tobacco and cigarette smuggling in Asia
}

\author{
J Collin, E LeGresley, R MacKenzie, S Lawrence, K Lee
}

Tobacco Control 2004;13(Suppl II):ii104-ii1 11. doi: 10.1136/tc.2004.009357

See end of article for authors' affiliations

.....................

Correspondence to: Dr Jeff Collin, Centre on Global Change and Health, London School of Hygiene and Tropical Medicine, Keppel Street, London WCIE 7HT, UK; jeff.collin@lshtm.ac.uk
Objectives: To examine the complicity of British American Tobacco (BAT) in cigarette smuggling in Asia, and to assess the centrality of illicit trade to regional corporate strategy.

Methods: Analysis of previously confidential documents from BAT's Guildford depository. An iterative strategy combined searches based on geography, organisational structure, and key personnel, while corporate euphemisms for contraband were identified by triangulation.

Results: BAT documents demonstrate the strategic importance of smuggling across global, regional, national, and local levels. Particularly important in Asia, contraband enabled access to closed markets, created pressure for market opening, and was highly profitable. Documents demonstrate BAT's detailed oversight of illicit trade, seeking to reconcile the conflicting demands of control and deniability.

Conclusions: BAT documents demonstrate that smuggling has been driven by corporate objectives, indicate national measures by which the problem can be addressed, and highlight the importance of a coordinated global response via WHO's Framework Convention on Tobacco Control.
$\mathrm{T}$ here is increasing recognition of the significance of cigarette smuggling as a threat to effective health policy. ${ }^{1}$ Importantly, this has been reflected in both negotiations for $^{2}$ and the final text of World Health Organization's Framework Convention on Tobacco Control (FCTC). ${ }^{3}$ This attention is partly attributable to the sheer scale of contraband, accounting for between $6-8.5 \%$ of global cigarette consumption ${ }^{4}$ or around one quarter of total exports. ${ }^{56}$ An additional impetus, however, has been the evidence of tobacco industry collusion in this trade provided by corporate documents. Analyses of these documents by journalists, ${ }^{7-9}$ non-governmental organisations, ${ }^{10}$ an international organisation, ${ }^{11}$ a parliamentary inquiry, ${ }^{12}$ and in academic journals ${ }^{513-16}$ have increased understanding of the dynamics of tobacco smuggling and created pressure for a substantive policy response.

This paper offers the first comprehensive analysis of cigarette smuggling in Asia, the critical region to the global tobacco industry ${ }^{17}$ and to the trajectory of the tobacco pandemic. ${ }^{18} 19$ The corporate documents of British American Tobacco (BAT) demonstrate both the enormity of smuggling in Asia and its central place in corporate strategy. While BAT has publicly denied involvement in smuggling, ${ }^{20-22}$ this paper analyses its internal documents to present a detailed case study of how and why BAT sought to control contraband flows across Asia.

\section{METHODS}

The limitations of tobacco document research ${ }^{23-26}$ and the specific difficulties of working with documents in BAT's Guildford depository ${ }^{27}$ have previously been described. Such problems are magnified by the multiple sensitivities surrounding smuggling. This paper draws on documents acquired during numerous visits to the Guildford depository since its opening in February 1999. The major methodological challenge entailed acquiring sufficient understanding of BAT's corporate structure and personnel to identify potentially relevant files, and, through triangulation, identifying the major euphemisms for contraband used within the documents. Further research of the depository's contents was then conducted on an iterative basis. Search terms were based on geography (for example, "Asia", "Indochi*", "Vietnam", "HCM"), organisational terminology (for example, "Asia Pacific RBU", "export", "NBD", "SUTL"), and key personnel (for example, "Paul Adams", "PN Adams", "PNA", "Patrick O'Keeffe", "O'Keefe", "PCOK").

\section{RESULTS}

\section{Tobacco smuggling and BAT documents}

While there are powerful indications that other tobacco companies have been complicit in smuggling, ${ }^{28}$ the industry documents have primarily provided evidence of complicity in smuggling by BAT. This disparity reflects differences in the diverse document collections created by the Minnesota litigation, the BAT documents exhibiting distinctive characteristics. In part, this may be attributed to BAT's late entry into the litigation and its apparent strategy of swamping the Minnesota plaintiffs with documents irrelevant to the lawsuit. ${ }^{29}$ This created a far broader document collection than might be expected given the terms of the Minnesota litigation.

Additionally, the documents from BAT often seem more candid than those from its competitors. ${ }^{30}$ This might be attributable to variations in corporate culture, a historically lower sense of vulnerability to litigation, ${ }^{31}$ or inadequate procedures for excluding sensitive material from paper records. Many of the most dramatic disclosures of tobacco industry misconduct have been obtained from BAT documents, including evidence of price fixing, ${ }^{32}$ systematic document destruction, ${ }^{33}$ and information concealment. ${ }^{27}$

This comparative candour of BAT documents is effectively illustrated via smuggling. Nonetheless, the illegality and sensitivity of such practices is reflected in apparent attempts to minimise their appearance in company records. ${ }^{7}$ The term smuggling appears very rarely within the documents, and understanding this illicit trade is reliant on deciphering a range of euphemisms or code words.

Abbreviations: BAT, British American Tobacco; DNP, duty not paid; FCTC, Framework Convention on Tobacco Control; GT, general trade; RBU, regional business unit; SUTL, Singapura United Tobacco Limited; TTCs, transnational tobacco companies; WDF, wholesale duty free 
Transit

The most easily recognised references to smuggling operations are offered by the term "transit". This unambiguously identifies contraband operations, as demonstrated by a 1989 definition discussing illicit imports in Asia:

With regard to the definition of transit it is essentially the illegal import of brands from Hong Kong, Singapore, Japan, etc. upon which no duty has been paid. ${ }^{34}$

Transit may have been viewed as an insufficiently oblique descriptor, with some indication that the use of the term was discouraged. In 1992 then territorial director Keith Dunt noted in the margins of a document: "Must not use 'transit' word". ${ }^{35}$

\section{General trade (GT)}

The phrase "General trade", often abbreviated to "GT", is seemingly BAT's most frequently used euphemism for contraband operations in Asia. While its meaning is not so immediately evident, an extensive review of the documents leaves little room for ambiguity. A 1994 draft document, for example, subdivided BAT's export business into three channels. "Domestic markets" identified trade "where the product is sold duty paid". "Duty free" (DF) designated exports to operators of facilities allowed to exclude excise from their retail price, subject to the qualification that where “DF business penetrates into the local domestic market... DF business can be regarded as GT".

GT refers to exports made for onward sale to another market other than the market to where product was shipped, and where the packaging would normally be non market specific. Such products would often have substitute coding to identify the customer and therefore the intended end market. ${ }^{36}$

Though opaque, the meaning of GT becomes clear by contrast with the reference to the other channels. Its use to designate contraband is further demonstrated by juxtaposition with legal sales. For example, an account of the first duty paid shipment to Burma in May 1993 notes that "(u)ntil then, Myanmar had always been a straightforward GT market for our brands", ${ }^{37}$ while a company plan from 1990 noted that in Taiwan "legal business has to some extent been compensated by GT sales". ${ }^{38}$

\section{Duty not paid (DNP)}

The use of "Duty not paid" or "DNP" as synonymous with contraband is most clearly demonstrated in Latin America. In Venezuela, for example, the DNP market is defined as:

\section{...the volume of cigarettes produced in Venezuela, exported (mainly to Aruba) and re-entering Venezuela as transit plus transit cigarettes produced elsewhere. ${ }^{39}$}

Elsewhere DNP sales are analysed separately from legal sales in both the duty paid and duty free markets, ${ }^{40}$ identifying DNP as describing contraband. Though used less frequently in documents relating to Asia, and slightly complicated by the government in Hong Kong using the

*A strong indication of concern to disguise references to smuggling is provided by the subsequent revision of this document. The description of domestic markets was essentially unaltered; the reference to penetration into the local market was deleted from the definition of duty free; while GT was replaced simply with "Exports All other business" phrase to refer to duty free, ${ }^{41}$ the region was a leading contributor to sales in this channel. A 1994 BAT global planning document noted:

In 1993, it is estimated that nearly $6 \%$ of the total world cigarette sales of 5.4 trillion were DNP sales. Eastern Europe and the Asia-Pacific region (c85 blln each) accounted for the majority of this volume... ${ }^{42}$

The above categories are by no means an exhaustive list of the euphemisms used in BAT documents to describe smuggled cigarettes. The volatility and sensitivity of such practices and a need to mask their inclusion in corporate documentation have yielded a long list of comparable terms. A 1993 document described "combined exports" as the principal driver of export growth in the Asia-Pacific region, and emphasised "the sensitivity of this source of profits"; ${ }^{43} \mathrm{a}$ 1993 review of distribution of BAT brands in China emphasised the dominance of "free market sales" and "unofficial imports"; 44 a 1988 account of transit in Vietnam emphasises BAT's need to disassociate itself from "parallel imports"; 45 while "wholesale duty free" (WDF) is reportedly a more recently favoured term. ${ }^{7}$

\section{Contraband as central to corporate objectives}

Smuggling can be identified as advancing key corporate objectives across multiple levels. Globally, contraband has accounted for a critical proportion of BAT's export sales and has played a major role in efforts to displace Philip Morris as global market leader. The 1994 review of BAT's management of export channels, for example, set itself the mission to "maximise BAT's share of the global export business":

This will be achieved irrespective of which sub-channel of exports is employed through the consistent management worldwide of $\mathrm{BAT}^{\prime} \mathrm{s}$ Brand Portfolio of International brands, and where appropriate BAT's Regional Brands, to satisfy consumer needs and achieve the corporate goals. ${ }^{46}$ (emphasis in original)

An appendix to an earlier draft of this review stated that the GT channel accounted for either $57 \%$ or $68 \%$ BAT's global export business, depending on how trade in Hong Kong, China, Djibouti, and Ghana was classified. ${ }^{36}$

At a regional level, in 1992 Barry Bramley, then CEO of BAT, identified the further development of GT sales as part of a twin track strategy in the Far East, "consolidating our position in the growing imported segments of the domestic markets as well as building on the successful General Trade business in the region" ${ }^{\prime 4}$ GT apparently accounted for $72 \%$ of exports for BAT's Asia-Pacific region from 1992 to March $1994 . .^{36}$

Nationally, anticipated returns from smuggled cigarettes have been critical in determining operational and investment strategies for some countries. Smuggling operations were key to BAT's broader efforts to penetrate the huge Chinese market, ${ }^{48}$ plans for Cambodia rested on its strategic value to regional contraband, ${ }^{49}$ and Laos seems to have been largely viewed in terms of its smuggling potential..$^{50}$ At local level, the documents provide remarkably detailed analyses of the suitability of specific regions, ${ }^{51}$ ports, ${ }^{50}$ islands ${ }^{52}$ and border crossings $^{53}$ as transit routes, and also describe detailed monitoring of the availability of smuggled brands in key cities such as Bangkok ${ }^{54}$ or Ho Chi Minh City. ${ }^{50}$

\section{Strategic advantages of cigarette smuggling}

This centrality is explained by a number of distinct advantages offered by successful sales of smuggled product. 
While often highly context specific, the documents indicate several key attributes that explain the significance of contraband in the region.

\section{Entering closed markets}

A key factor in the particular importance of contraband in Asia is that several target markets were effectively closed to legitimate imports, leaving smuggling as the sole means of ensuring the availability of international brand cigarettes. In Burma part of the comparative advantage of transit seemingly lay in BAT's inability to reliably import legal cigarettes. $^{55}$ In the early 1990s Vietnam operated a ban on imported cigarettes, but BAT's marketing department emphasised the strong performance of contraband BAT brands in a SWOT analysis:

\section{STRENGTH[S]}

1. [State Express] 555 with its high level of awareness and demand has prompted wholesalers and retailers to stock the brand despite the ban and the risk.

2. SUTL with its strong network of customers in Cambodia have been able to capitalise on the demand of the Vietnamese customer despite the ban. ${ }^{50}$

Thailand's market was also formally closed to TTCs [transnational tobacco companies] until 1990, ${ }^{56} 57$ but contraband operations enabled thriving trade. A 1988 report on a visit to Thailand estimated that "BAT's average monthly transit volume is about $22 \mathrm{mn}$... earning a total group trading profit of the order of $£ 1 \mathrm{mn}$ p.a." 58

\section{Pressure for market opening}

Smuggling in Asia has also been used as a means of exerting political leverage to secure market opening. ${ }^{159}$ In Thailand, for example, exploitation of contraband was presented as part of a broader strategy to undermine Thailand's ban on imports:

From a range of options in this situation, BAT's best strategy would appear to be: i) to continue to endorse the US pressure for legalization of imports, ii) to support the transit opportunities with internal promotion, and iii) to evaluate the possibility of a modest joint venture... ${ }^{58}$

While the existence of substantial contraband markets served to undermine the perceived viability of import bans, complicity in illegal operations could also heighten sensitivities and become a political liability. The documents indicate increasing concern about transit as the prospect of market opening increased. A 1989 document cautions against overtly infringing Thailand's advertising regulations, a concern reportedly shared within Philip Morris:

The current high level of advertising for international brands which are only available through transit is a particularly prominent windmill for the proponents of this to joust at. Dollison [PM Corporate Affairs] has suggested that all companies moderate their advertising activities over this sensitive period. ${ }^{60}$

Similar disquiet is expressed concerning negotiations for a Burma trading office that would facilitate legal importation and distribution, ${ }^{55}$ while governmental awareness of BAT's complicity in smuggling evidently complicated negotiations for a joint venture in Vietnam. ${ }^{61}$
Undermining regulation

The ability to undermine effective health policy has been critical to the value of smuggling to tobacco companies. Successful orchestration of increased contraband flows with media pressure to curb taxation policy has occurred in countries such as Canada, ${ }^{62}$ Sweden, ${ }^{1}$ and the UK. ${ }^{63}$ BAT documents provide more detailed accounts of how the reliable availability of smuggled cigarettes contributed to efforts to influence public policy. In Bangladesh, ${ }^{10}$ documents suggest that BAT both exerted substantial control over flows of contraband cigarettes ${ }^{64-66}$ and presented such flows to the government as proof of the need to reverse increased excise. ${ }^{67}$ In Burma, following protracted negotiations between government and traders, a review of duty levels was presented as a quid pro quo for a crackdown on transit according to a regional business plan..$^{50}$

A variant of this approach was seen in Thailand when TTCs warned the Deputy Prime Minister that proposed tobacco control legislation would escalate smuggling. ${ }^{68}{ }^{69}$ Upon the opening of the Thai market to legal imports, TTCs seemingly colluded in setting pricing at a high level, believing that readily available smuggled brands would force a reduction in tax:

\section{PM/RJR/RPE are advocating market entry [into Thailand] at $40 \mathrm{Baht}$ in order to demonstrate that the legal business will be minimal, GT will continue and therefore revenue lost. The belief is that the Thai's [sic] will then reduce the Duty. $^{70}$}

Similarly, 1995 proposals in anticipation of an ingredients disclosure regulation included: "We need to be ready to pump in GT stocks in case the supply is disrupted by the Regulation." $^{\prime 71}$

\section{Greater desirability of smuggled product}

In some contexts part of the comparative advantage of smuggled cigarettes may lie in a perceived superiority to legal brands. ${ }^{63}{ }^{72}$ A BAT commissioned study in Indonesia noted a preference for contraband versions of international brands, "supposed to be 'original from abroad"..$^{73}$ Focus groups of Marlboro smokers in Malaysia in 1987 reported that smoking smuggled imports gave "a feeling of "class"' and was preferred to locally produced Marlboro. ${ }^{74}$

\section{Highly profitable}

The basic rationale for complicity in smuggling, of course, was that it yielded high levels of profit. The risks associated with transit were clear, but documents suggest that BAT's corporate strategy calculated that illegality was outweighed by profitability:

Transit trade is volatile, and disruptive to the orderly operation of markets. It is in BAT's interest that markets are legal, taxed and controlled. However our primary responsibility is to meet consumers' demands as profitably as possible. ${ }^{75}$

While acknowledging ethical questions raised by encouraging the DNP segment, Keith Dunt outlined his own view as being "that it is part of your market and to have it exploited by others is just not acceptable". ${ }^{76}$

In some contexts, contraband was operating so successfully as to question the merits of developing legitimate business. A 1988 report predicting further opening of Asian markets described the trend as posing "a threat to traditional transit sales where BAT (UK\&E), in particular, have been relatively strong". ${ }^{45}$ A 1994 discussion of a proposed joint 
venture in Burma highlighted concerns about profitability given its potential impact on illegal GT sales:

555 is our major brand priority. Were B\&H to be locally produced from Year 1 and 555 only in Years 4-5, B\&H may achieve an 'unfair' advantage. (we may come under pressure to reduce GT)...

"The JV financials are not net of cannibalisation of GT (eg Lucky Strike). Clearly there will be a knock on effect to BATCo. profit. ${ }^{77}$

An earlier proposal to introduce duty paid imports into Burma discussed "the level of subsidy" this would require "bearing in mind costs as against $\mathrm{GT}^{\prime} .{ }^{78}$ In Taiwan legal sales of 555 are similarly described: "to some Taiwan has to some extent been compensated by GT sales" ${ }^{38}$

BAT documents suggest a broad preference for gradually reducing reliance on the volatile contraband markets in favour of more predictable legitimate business. ${ }^{47}$ BAT's $^{\prime}$ strategy for the opening of the Thai market sought to increase "the importance of domestic end markets as against the more volatile G.T. business":

As part of the "raison d'etre" of BATUKE it is key that returns from the volatile, albeit good margin and often GT markets are re-invested to achieve the more longer term objectives of BATUKE, i.e to establish a dominant presence in stable domestic environments with a strong brand portfolio. ${ }^{79}$

Importantly, the logic of this shift does reiterate the centrality of smuggling to achieving BAT's goals in Asia, albeit with an expectation that this would decline. Furthermore, the dominance of contraband in Thailand was remarkably persistent, accounting for an estimated $60 \%$ of total volume in $1994 .^{80}$

\section{Managing a risky business}

The BAT documents demonstrate the complexity and diversity of contraband operations across Asia, highlighting the fact that smuggling in the region has not been synonymous with or entirely controlled by BAT. The documents indicate, for example, that competitors' brands were also smuggled, ${ }^{81} 82$ and in Malaysia the extensive availability of smuggled kreteks constituted unwelcome competition. ${ }^{83}$ There are also indications of a lack of cohesion across BAT's operating companies, ${ }^{10} 8485$ while the illicit nature of the business meant that information was often imperfect and other parties could be unreliable. ${ }^{80} 8687$

Notwithstanding such qualifications, the documents indicate that BAT went to great lengths to ensure that contraband operations fulfilled corporate objectives.

\section{Awareness and involvement of senior personnel} The significance of contraband operations for BAT meant that awareness and involvement reached the highest levels of the organisation. ${ }^{88}$ Among issues for discussion by Sir Patrick Sheehy and Ulrich Herter, then respectively chairman and managing director of BAT Industries, during a visit to the region in 1994 was clarification of management responsibility for transit. ${ }^{89}$ In a March 1994 memo, Paul Adams, then regional manager and now BAT's chief executive, clarified that primary responsibility for GT business lay with his regional business unit (RBU):

All GT business in Asia Pacific should now be handled by the RBU. Can we please check with [B\&W vice president]
Tom Whitehair that we are now handling all GT and that therefore they are not using SUTL for any GT business. ${ }^{90}$

Specific responsibility for managing smuggling operations in Asia was apparently delegated to Patrick O'Keeffe, regional exports manager. The job description for this post again emphasises BAT's detailed oversight of contraband operations:

(A)s the Coordinator of GT sales world-wide, his responsibilities include: ...agreeing [to] the proposed price structure of all major orders to the General Trade... Maintenance of profiles of all main dealers, and monitoring of supply routes... [and] Proactive search for new GT business.91

The requirement to identify new contraband business again illustrates that BAT's involvement far exceeded merely monitoring illicit sales. O'Keeffe (PCOK) sought to arrange pricing in Vietnam of imports of State Express 555 smuggled from Singapore in Vietnam so as not to undermine the launch of a locally produced version:

PCOK explained that BAT wanted SUTL to ensure a retail price of 11000 Dong on 555 SDNP [Singapore Duty Not Paid] in HCM [Ho Chi Minh City] to allow 555 MIV [Made in Vietnam] an opportunity to establish itself at 10000 Dong. ${ }^{92}$

\section{Singapura United Tobacco Limited (SUTL)}

This indirect intervention in smuggled markets via SUTL (Singapura United Tobacco Limited) represents the principal method by which BAT sought to control contraband across Asia. SUTL was a long time distribution partner of BAT, and did handle legal sales of BAT products, but documents demonstrate that SUTL was also effectively granted a licence to oversee smuggling on BAT's behalf throughout much of Asia..$^{45}$ The mission statement for SUTL's distribution strategy 1995-99 was defined as:

To maximise BAT's market and profit shares of the SouthEast Asia/ Indian Sub-Continent export business through the most efficient distribution of international and regional brands, irrespective of sub-channel (Domestic, Duty Free, GT) to our customers. ${ }^{93}$

In response to questioning by the Health Select Committee, Deputy Chairman Ken Clarke insisted that SUTL was "a perfectly legitimate wholesaler" and that, beyond serving as "our Singapore wholesaler... it is not controlled by BAT". ${ }^{94}$ By contrast, the corporate documents indicate substantial awareness of SUTL's role in smuggling, even assessing the proportion of time spent on GT business by key SUTL personnel. ${ }^{95}$ More significantly, the documents extensively demonstrate that contraband operations by SUTL occurred under the direction of BAT.

\section{Direction and control}

This is evident in encouragement from BAT for SUTL to expand smuggling or identify new routes. Minutes from a 1991 meeting with SUTL record senior BAT executive Anthony Pereira asking "how we were progressing with efforts to increase transit". ${ }^{96}$ Similarly, a 1993 Singapore meeting with SUTL discussed imports to China, noting that enquiries for legal duty paid sales would be handled by BAT China whereas "SUTL are encouraged to expand overland routes through Indochina". ${ }^{97}$ The control exerted by BAT is evident in Bangladesh, ${ }^{10}$ a 1993 memo noting that "(p)ricing 
of transit brands are to be advised by $\mathrm{IBG}^{\prime \prime},{ }^{98}$ the International Brand Group at UK headquarters, while BAT were also apparently able to intervene to amend contraband flows. ${ }^{99}{ }^{100}$ The close relationship is also demonstrated by Alec Stuart joining SUTL as General Manager in 1992, having previously held BAT managerial positions in Malaysia, Singapore, and Bangaldesh. ${ }^{93}$

The documents also indicate persistent efforts to increase BAT's control over contraband business. A 1987 meeting described "improving our knowledge of the transit end markets and taking more control of the business". ${ }^{101}$ An internal restructuring was proposed in 1988 to create an organisation capable of building legal sales in emerging markets "whilst supervising and controlling existing transit business". ${ }^{45}$ The 1994 review of export channel management preferred "exclusivity of supply arrangements via one distributor so as to facilitate maximum control", highlighting the need to "control pricing as the key variable in managing in a co-ordinated and consistent fashion all the sub-channels of Exports". ${ }^{102}$

\section{Running legal business to support contraband}

BAT's capacity to exploit contraband flows was enhanced by the seemingly widespread practice of coordinating operations across legal and illegal channels. ${ }^{92} 99100$ In several markets a small legal operation was established to provide protective cover for smuggled sales, hence the term "umbrella operations". ${ }^{10}{ }^{11}{ }^{103}$ A token legal presence enabled marketing and promotional activities to be undertaken in support of contraband. The first duty paid shipment to Burma was expected to "give a legal coverage for our marketing activities", ${ }^{104}$ while in Laos a "legal base would be established to enable support" ${ }^{\prime 50}$ for contraband from Cambodia.

In other contexts the dividing line between legal and illegal business could be effectively blurred; "'legal' imports could hide large scale transit activity". ${ }^{105}$ Documents demonstrate that ostensibly legitimate duty free sales have provided an effective means of supplying smuggled cigarettes. A 1994 monthly review for Thailand noted that supply of transit cigarettes was good in most areas while "in Bangkok leakage of duty-free stocks is high". ${ }^{54}$ In 1991 one of three main methods of reaching the market in Burma was described as being "Partial Duty Paid":

\section{ii) Partial Duty Paid-Product arrives at ports less rigidly 'policed'. \\ Duty is, therefore, paid on some of the amount imported. This will vary according to the compliance of the customs personnel-the usual point of entry being Moulmein. ${ }^{50}$}

A 1994 assessment of competitors' contraband in the Philippines noted the significance of duty free sales as an enabling factor. Alongside organised transit via Malaysia and Indonesia the report identified "personal transit into 'free markets' ex official duty free retail outlets" and "leakage of product in transit for re-export". ${ }^{82}$ It was recommended that BAT should focus on duty free shops as "the main semi-legal distribution method open to us for penetrating the free markets":

ii) BATCo should concentrate on developing visibility and volume through the duty free shops, to attract personal transit volume into certain key free markets like Chinatown for SE555. To a degree this is already being achieved... Consideration could be, however, given to some POS [point of sale]/consumer promotional activity in this area, providing legality issues could be addressed eg advertising of consumer promotions at duty free outlets. ${ }^{82}$
The sale of duty free cigarettes by international hotels in India provided "legal cover for promotions and POS [point of sale] displays". ${ }^{106}$ A 1992 document indicates that this seemingly marginal channel provided for substantial leakage into domestic sales:

Of the 70 millions shipped into India last year, I am informed that around $10-20 \%$ is sold in the duty free outlets to travellers while the remainder seeps out into the local market. ${ }^{107}$

In East Asia the purchase of confiscated contraband at customs auctions also provided "a shelter for subsequent purchases from other sources". ${ }^{108}$

\section{Managing sensitivity, ensuring deniability}

The documents demonstrate widespread awareness among senior BAT personnel of the questionable nature of key export operations, ${ }^{35} 76102$ the risks associated with such involvement, ${ }^{102}{ }^{109}$ and the problems posed for relations with governments. ${ }^{6110}$ The strategic challenge for BAT was to maintain both careful management of illicit trade and sufficient separation from it to ensure deniability. This balancing act is evident in BAT's relations with SUTL, and became more difficult to maintain in the context of joint ventures or market opening.

BAT's 1993 Asia Pacific Review noted that that long term cooperation with SUTL in both legal and illicit trade ran the risk of "unacceptably high exposure" for BAT, and it was deemed "[n]ot prudent to maintain GT trading links with SUTL and to accept as partner in any of the proposed joint ventures". ${ }^{109}$ In 1993 Fred Combe of BATUKE Singapore similarly stated that, in Cambodia, Laos, and Myanmar, BAT would only formalise agreements with "bona-fide duty paid distribution companies... due to General Trade sensitivities". ${ }^{111}$

Arguably the most explicit statement of BAT's approach to handling contraband operations is provided by a 1988 document discussing Vietnam. This establishes a clear rationale for balancing direction and deniability:

Transit: the nature of this business brings paradoxical requirements of an arm's length approach and close supervision. Where BAT has legitimate interests in the end markets it must be able to disassociate itself from direct involvement in parallel imports. Nevertheless, indiscriminate sourcing can and does lead to potentially embarrassing problems.

This conflict can be resolved by maintaining close control over the accredited export agent in the home market, backed up market intelligence garnered from end market visits... ${ }^{45}$

\section{DISCUSSION}

Addressing the Global Congress on Combating Counterfeiting in May 2004, BAT's new chief executive Paul Adams observed that "tax revenues are essential to government services, and this is particularly so in developing countries where economic development and growth are strongly linked to it". ${ }^{12}$ By contrast, the documents presented above demonstrate how BAT's corporate strategy for Asia relied on illicit trade that systematically undermines such revenues. While there is much that remains unknown about tobacco smuggling, these documents provide a powerful resource for the development of effective policy responses.

Despite the daunting scale of the problem outlined in the documents, the analysis leaves scope for optimism that it can be effectively addressed. The abolition of duty free sales, for example, would remove a key facilitator of contraband flows 


\section{What this paper adds}

Asia is the key target region in the industry's global expansion. This paper offers the first comprehensive regional analysis of corporate documents focused on smuggling, highlighting how BAT sought to direct this illicit trade and its critical role in corporate strategy.

via "leakage" into domestic sales and its protective coverage for promotion of illicit sales.

Abandoning the practice of reselling confiscated stocks of smuggled cigarettes ${ }^{113} 114$ would remove the possibility of traders profiting from tighter enforcement. Importantly, the documents demonstrate that improved enforcement can effectively curtail the trade in contraband. In Thailand, an increased security presence at border crossings with Burma ${ }^{53}$ and Malaysia ${ }^{52}$ reportedly curtailed flows of transit stock, while the comparatively closed and secretive nature of the Thai transit market made it more difficult to operate successfully. ${ }^{80}$ A similar point is made by contrary examples where complicity of government officials and agencies has facilitated contraband. ${ }^{52} 58115$

A striking feature of the above documents is the extent to which smuggling has been strategically driven to advance BAT's corporate objectives, in stark contrast to public denials of complicity. ${ }^{20-22}$ This heightens the need for political will both to halt the role of contraband in undermining tobacco control and to hold to account those active or complicit in such illicit trade. Given this need, and in light of the evidence presented above, the recent announcement by the UK's Department of Trade and Industry ${ }^{116}$ that its investigation into BAT's alleged involvement in smuggling would be neither published nor result in any further action is extremely disappointing. The recent agreement between the European Union (EU) and Philip Morris included provisions for compensation and seizure payments as well as protocols for compliance and for tracking and tracing. ${ }^{28} 117$ This could establish a valuable precedent for broader efforts to recover lost revenue and to prevent future smuggling.

Further encouragement is provided by the inclusion of a commitment to tackling contraband within the FCTC. Contraband is an inherently transnational problem that requires a coordinated global response, and its inclusion within the FCTC is an important first step. ${ }^{118}{ }^{119}$ However, the complexity and scale of cigarette smuggling requires a more detailed and enforceable policy regimen. Specific suggestions include cessation of duty free sales as is the case within the EU; licensing of manufacturers and other parties involved in the distribution process; chain of custody markings for exported cigarettes; and stiffer penalties for those caught smuggling. ${ }^{5}$ There is also a clear need for ratification of the FCTC to be rapidly followed by progress towards a specific protocol to counter the illicit trade in tobacco products.

\section{ACKNOWLEDGEMENTS}

This work was supported by the Rockefeller Foundation's Trading Tobacco for Health Initiative and by NIH grant R01 CA091021-03: "Globalization, the Tobacco Industry and Policy Influence".

Documents cited in this paper not currently available on existing websites will be posted on the Tobacco Control Research page on the London School of Hygiene and Tropical Medicine website http:// www.lshtm.ac.uk/cgch/tobacco/index.html.

\section{Authors' affiliations}

J Collin, R MacKenzie, S Lawrence, K Lee, Centre on Global Change and Health, London School of Hygiene and Tropical Medicine, London, UK

E LeGresley, Tobacco Control Consultant, Ottawa, Ontario, Canada

\section{REFERENCES}

1 Joossens L, Chaloupka F, Merriman D, et al. Issues in the smuggling of tobacco products. In: Jha P, Chaloupka F, eds. Tobacco control in developing countries. Oxford: Oxford University Press, 2000:393-406.

2 International Conference on Illicit Tobacco Trade. 30 Jul-1 Aug 2002. New York http://www.atf.gov/tobacco/icitt/index.htm.

3 World Health Organization. Framework Convention on Tobacco Control. 21 May 2003. http://www.who.int/tobacco/areas/framework/final_text/en/ [Accessed 6 Jul 2004].

4 Merriman D, Yurekli A, Chaloupka F. How big is the worldwide cigarette problem? In: Jha P, Chaloupka F, eds. Tobacco control in developing countries. Oxford: Oxford University Press, 2000:365-392.

5 Joossens L, Raw M. Turning off the tap: the real solution to cigarette smuggling. Int J Tuberc Lung Dis 2003;7:214-22.

6 Joossens L. An update on cigarette smuggling. Warsaw, Poland: Third European Conference on Tobacco or Health, 22 June 2002.

7 International Consortium of Investigative Journalists. Tobacco companies linked to criminal organizations in lucrative cigarette smuggling. The Centre for Public Integrity, 3 March 2001. http://www.publici.org/dtaweb/report asp? ReportID = 62\&L1 = 30\&L2 = 10\&L3 = 10\&L4 = 0\&L5 = 0\&Display = ICIJ

8 Campbell D, Beelman S, Schelzig E. Paper trail to markets of the East. The Guardian 2 February 2000 http://www.guardian.co.uk/Print/ 0,3858,3957775,00.html.

9 Beelman M, Campbell D, Ronderos MT, et al. Major tobacco multinational implicated in cigarette smuggling, tax evasion, documents show. 31 Jan 2000. The Center for Public Integrity. http://www.publicintegrity.org/ report. aspx? aid $=335 \&$ sid $=100$.

10 Campaign for Tobacco-Free Kids. Illegal pathways to illegal profits: the big cigarette companies and international smuggling. Washington DC: Campaign for Tobacco-Free Kids, 2000.

11 EMRO. Coveting Iran:tThe infiltration and exploitation of Iran by global tobacco companies. Cairo: EMRO, $2001 \mathrm{http}: / / \mathrm{www}$.emro.who.int/TFl/ IranReport.doc [Accessed $5 \mathrm{Jul} 2004$ ]

12 UK House of Commons. Select Committee on Health Second Report. The Tobacco Industry and the Health Risks of Smoking. 14 June 2000. http:// www.parliament.the-stationery-office.co.uk/pa/cm 199900/cmselect/ cmhealth/27/2707.htm.

13 Thompson F. Cigarette smuggling and public health [editorial]. Int I Tuberc Lung Dis 2003;7:207.

14 Joossens L, Raw M. How can cigarette smuggling be reduced? [Education and debate] BMJ 2000;321:947-50.

15 Shafey O, Cokkinides V, Cavalcante TM, et al. Case studies in international tobacco surveillance: cigarette smuggling in Brazil Tobacco Control 2002;11:215-19.

16 Joossens L, Raw M. Cigarette smuggling in Europe: who really benefits? Tobacco Control 1998;7:66-71.

17 Herter U. Industry perspective: a perspective on the global tobacco market. 2000

18 World Health Organization. The world health report 2002: reducing risks, extending healthy life. Geneva: WHO, 2002

19 Gajalakshmi CK, Jha P, Ranson K, et al. Global patterns of smoking and smoking-attributable mortality. In Jha P, Chaloupka F, eds. Tobacco control in developing countries. Oxford: Oxford University Press, 2000:1 1-39.

20 British American Tobacco. Smuggling: Our View. 16 February 2000. www.bat.com [Accessed 16 Jul 2004]

21 British American Tobacco. Supplementary Memorandum (TB 28F): Smuggling Allegations. 8 March 2000. Health select Committee, Second Report 1999-2000, Minutes of Evidence and Appendices http:// www.parliament.the-stationery-office.co.uk/pa/cm 199900/cmselect/ cmhealth/27/27ap28.htm [Accessed 16 Jul 2004]

22 Clarke K. Dilemma of a cigarette exporter. The Guardian. 3 Feb 2000. http://www.guardian.co.uk/bat/article/0,2763,191288,00.htm [Accessed $16 \mathrm{Jul}$ 2004].

23 MacKenzie R, Collin J, Lee K. The tobacco industry documents: an introductory handbook and resource guide for researchers. London: London School of Hygiene \& Tropical Medicine, 2003. http://www.lshtm.ac.uk/ cgch/tobacco/Handbook\%2008.07.03.pdf [Accessed 5 July 2004].

24 Bero L. Implications of the tobacco industry documents for public health and policy. Ann Rev Public Health 2003;24:267-88.

25 Balbach E. Tobacco industry documents: comparing the Minnesota Depository and internet access. Tobacco Control 2002;11:68-72.

26 Malone RE, Balbach, eds. Tobacco industry documents: treasure trove or quagmire? Tobacco Control 2000;9:334-8.

27 Muggli ME, LeGresley EM, Hurt RD. Big tobacco is watching: British American Tobacco's surveillance and information concealment at the Guildford depository. Lancet 2004;363:1812-19.

28 Financial Times. Philip Morris to confirm deal on smuggling lawsuits. 9 July 2004. http://search.ft.com/search/article.html?id $=040709000446$ [Accessed $15 \mathrm{Jul}$ 2004].

29 Ciresi M, Walburn R, Sutton T. Decades of deceit: document discovery in the Minnesota tobacco litigation. William Mitchell Law Review 2002; 25:477-566

30 Lee K, Gilmore AB, Collin J. Looking inside the tobacco industry: revealing insights from the Guildford Depository. Addiction 2004;99:394.

31 Collin J, Lee K, Gilmore AB. Unlocking the corporate documents of British American Tobacco: an invaluable global resource needs radically improved access. Lancet 2004;363:1746-7.

32 Economist. com The price is not quite right. The Economist, 5 July 2001 http://www.ash.org.uk/html/conduct/html/pricefixing.html [Accessed 9 Jul 2004]. 
33 Liberman J. The shredding of BAT's defence: McCabe $\vee$ British American Tobacco Australia. Tobacco Control 2002;11:271-4.

34 BAT. Taiwan Transit Study. 25 Aug 1989. British American Tobacco Bates No. 302000021 . Available from Guildford Depository.

35 Dunt K. [BAT Letter to Graham Burgess; marginalia in Dunt's hand]. 6 Oct 1992. British American Tobacco. Bates No. 301675321. Available from Guildford Depository.

36 O'Keeffe PC. Export Channel Management, Draft. 13 Jun 1994. British American Tobacco Bates No. 50392317/2326. Available from Guildford Depository.

37 Godfrey P. State Express 1994 Brand Plan, Myanmar. 4 Oct 1993. British American Tobacco. Bates No. 50299308/9337. Available from Guildford Depository.

38 BATUKE. Company Plan, 1991-1995, Part 1. 10 Oct 1990. British American Tobacco Bates No. 301615548/5583. Available from Guildford Depository.

39 BAT Internal memo: Venezuelan Market Definitions and Assumptions. (File owner Keith Dunt) 25 Aug 1989. British American Tobacco. Bates No. 500025647/5648. Available from Guildford Depository.

40 BAT. (BJ0343). British American Tobacco. Bates No. 503861672/1856. Available from Guildford Depository.

41 Broughton M. Evidence to the Health Select Committee, 16 Feb 2000 , http://www.parliament.the-stationery-office.co.uk/pa/cm 199900/ cmselect/cmhealth/27/0021605.htm [Accessed 15 Jul 2004].

42 BAT. BATCo Global Five-year Plan 1994-1998. Bates No. 500018206/ 8211. Available from Guildford Depository.

43 BAT. Notes from BEC Meeting to review the Asia Pacific Regional Plan 19941998. 22 Nov 1993. British American Tobacco. Bates No. 500018295/ 8305.

44 Lovett N. Distribution Initiatives Within PRC. 18 Nov 1993. British American Tobacco. Bates No. 500014779/3780. Available from Guildford Depository.

45 Ross IA. Proposed re-definition of Market Responsibilities. 16 Dec 1988. British American Tobacco. Bates No. 500014649/4660. Available from Guildford Depository

46 O'Keeffe P. Export Channel Management Draft. 26 Jul 1994. British American Tobacco. Bates No. 503932264/2272. Available from Guildford Depository.

47 BAT. B.A.T. (U.K. and Export) Limited. Company Plan 1993-1997. Oct 1992. British American Tobacco. Bates No. 502573663/3719. Available from Guildford Depository.

48 Lee K, Gilmore AB, Collin J. Breaking and re-entering: British American Tobacco in China 1979-2000. Tobacco Control 2004;13(suppl II):ii88-95.

49 MacKenzie R, Collin J, Chim S, et al. "Almost a role model of what we would like to do everywhere": British American Tobacco in Cambodia. Tobacco Control 2004;13(suppl II):ii1 12-17.

50 BAT. Indochina/Myanmar Far East South Company Plan. 1992. Aug 1991 British American Tobacco. Bates No. 300013788/3907. Available from Guildford Depository

51 O'Keeffe PC, O' Regan A. Presentation to Mr U Herter: China's Borders. 5 May 1994. British American Tobacco. Bates No. 503932296/2297. Available from Guildford Depository.

52 Davidson B. File note on Malaysia Trip. 19 Apr 1989. British American Tobacco. Bates No. 301666379/6382. Available from Guildford Depository.

53 Horne S. Myanmar: Embassy Review/Proposal. 30 Nov 1992. British American Tobacco. Bates No. 300028596. Available from Guildford Depository.

54 Lavin M. Thailand monthly review November, 1994. 8 Nov 1994. British American Tobacco. Bates No. 500206892/6955. Available from Guildford Depository.

55 Horne S. [BATUKE Fax to Jim Gregory] 12 Nov 1992. British American Tobacco. Bates No. 500129215. Available from Guildford Depository.

56 Vateesatokit P, Hughes B, Ritthiphakdee B. Thailand: winning battles, but the war's far from over. Tobacco Control 2000;9:122-7.

57 Chantornvong S, McCargo D. Political economy of tobacco control in Thailand Tobacco Control 2001;10:48-54

58 Norsworthy M. [Note to Messrs: D.G. Heywood, R.A. Crichton, D.K. Thorpe, M. Murray, S.M. Aitken re: Thailand]. 10 Nov 1988. British American Tobacco. Bates No. 301667299/7303. Available from Guildford Depository.

59 Chantornvong S, McCargo D. Political economy of tobacco control in Thailand, Tobacco Control 2001;10:48-54.

60 Ross IA. [Letter from IA Ross to Ronnie A C Crichton]. 27 Jan 1989. British American Tobacco. Bates No. 301667231/7234. Available from Guildford Depository.

61 Manning JC. Vietnam Correspondence. 19 Jun 1991. British American Tobacco. Bates No. 301734282. Available from Guildford Depository.

62 Cunningham R. Smoke and mirrors: the Canadian tobacco war. Ottawa: International Development Research Centre, 1996

63 Collin J. Think Global, smoke local: transnational tobacco companies and cognitive globalisation. In Lee K, ed. Globalization and health: case studies. London: Palgrave, 2003:61-85.

64 Duncan RMH. [Bangladesh Tobacco Company Fax to Tim Wilson of BAT] 4 Jan 1991. British American Tobacco. Bates No. 503914292. Available from Guildford Depository.

65 BAT. Bangladesh, Imports of BHSF by BTC. Marginalia note on additional copy of document from Steve Smith to David Aitken. 16 Dec 1993. British American Tobacco. Bates No. 301702136. Available from Guildford Depository.
66 Combe F. Company Plan 1994-8: Asia Pacific South/ SUTL: Domestic. Sep 1993. Bates No. 500282683/2793. Available from Guildford Depository. 67 Accorda R. [Bangladesh tobacco Company Letter to Dr Akbar Ali Khan, Bangladesh National Board of Revenue]. 21 Nov 1994. British American Tobacco. Bates No. 600515551. Available from Guildford Depository.

68 Trairatanobhas V. Industry Meeting with Deputy Prime Minister Meechai Rachuphan at Government House British American Tobacco. 30 Sep 1991. British American Tobacco. Bates No. 5025757203/7207. Available from Guildford Depository.

69 Mackenzie R, Collin J, Sriwongcharoen K, et al. "If we can just 'stall' new unfriendly legislations, the scoreboard is already in our favour": transnational tobacco companies and ingredients disclosure in Thailand. Tobacco Control 2004;13(suppl II):ii79-87.

70 Scott MJ. General Comments / Action Points Arising out of Market Visits, 1330 November 1990. 3 Dec 1990. British American Tobacco. Bates No. 300028564/8570. Available from Guildford Depository.

71 Leung A. Thailand ingredient Regulation. 3 Jul 1995. British American Tobacco. Bates No: 800162141-2142. Available from Minnesota Tobacco Depository.

72 Dreyfuss R. Big Tobacco Rides East, Mother Jones online January-February 1999 http://www.motherjones.com/mother_Jnes/JF99/dreyfuss.html [Accessed 5 Jul 2004].

73 BAT Indonesia. A Study on the Smokers of International Brands. British American Tobacco. nd. (1985?). Bates No. 400458935/9056. Available from Guildford Depository.

74 Philip Morris. Cigarette Group Held on 24th June, 1987. 27 Jun 1987. Philip Morris. Bates No. 2504047228/7233. http:// legacy.library.ucsf.edu/tid/ovt19e00.

75 BAT. Tobacco Strategy Group. Internal draft strategy document. 19 May 1993. British American Tobacco 203469483/9485. Available from Guildford Depository.

76 Dunt K. [BAT Letter to Eduardo Grant, Noblexa-Picardo]. 24 Jun 1992 British American Tobacco. Bates No. 301674939/4940. Available from Guildford Depository.

77 Adams P. Market Note: Myanmar. 26 Jun 1994. British American Tobacco. Bates No. 500017045. Available from Guildford Depository

78 Horne S. [BAT FAX to Jim Gregory]. 30 Nov 1992. British American Tobacco. Bates No. 301630419. Available from Guildford Depository.

79 BATUKE. Review of Thailand Domestic Market Initiative. 1991. British American Tobacco. Bates No. 300028752/8764. Available from Guildford Depository.

80 O'Regan R. Trip Notes [Myanmar, Cambodia, Laos and Thailand, 15th to 23rd May 1994] 15 Jun 1994. British American Tobacco. Bates No. 503932340/2343. Available from Guildford Depository.

81 Hacking I. (?) [BAT Handwritten note] 30 Jan 1992. British American Tobacco. Bates No. 303557790. British American Tobacco. Available from Guildford Depository.

82 BAT (N. Lovett identified as author in accompanying letter from Anthony Pereira to Paul Adams). Report: Philippines - A Draft Overview and Recommendation. 7 Jan 1994. British American Tobacco. Bates No. 500045818/5828. Available from Guildford Depository.

83 Viner P. 1993-1997 Corporate Plan. 1992(?). British American Tobacco. Bates No. 500349939. Available from Guildford Depository.

84 Reynolds C. [BATUKE Letter to Wyn Jones, Malaysian Tobacco Company]. 21 Apr 1987. British American Tobacco. Bates No. 301666383. Available from Guildford Depository.

85 Coburn RJM. [Memo to MJ Scott, DK Thorpe, W Rose, BATUKE]. 24 May 1988. British American Tobacco. Bates No. 301666416 . Available from Guildford Depository.

86 Downham ML. Shipping cigarettes from Medan, Indonesia through Cambodia to Vietnam. 25 Apr 1990. British American Tobacco Bates No. 400402662/2663. Available from Guildford Depository.

87 STC. Monthly Review-December 1993. British American Tobacco Bates No. Available from Guildford Depository.

88 BAT. [Regional Business Unit Meeting -Secret]. 26 Nov 1993. British American Tobacco. Bates No. 503811076 . Available from Guildford Depository.

89 Adams P. Visit of Sir Patrick Sheehy, 13th April 1994. 11 Feb 1994. British American Tobacco. Bates No. 500017305. Available from Guildford Depository.

90 Adams P. Duty free and GT Sales. 14 Mar 1994. British American Tobacco. Bates No. 500017237. Available from Guildford Depository.

91 BAT. (PC Godby, File owner). Exports 1993-1996. British American Tobacco. Bates No. 503952268/2271. Available from Guildford Depository.

92 BAT. BAT/ SUTL Meeting 11 Nov 1994. 24 Nov 1994. British American Tobacco. Bates No. 503868731/8737. Available from Guildford Depository.

93 Combe F. SUTL Distributor Strategy 1995-1999. Aug 1994. British American Tobacco. Bates No. 500045730/5752. Available from Minnesota Depository.

94 UK House of Commons. Select Committee on Health Second Report. The Tobacco Industry and the Health Risks of Smoking. Minutes of Evidence: Examination of witnesses (Questions 1400-1419) Wednesday 16 February 2000, http://www.parliament.the-stationery-office.co.uk/pa/cm 199900/ cmselect/cmhealth/27/0021607.htm.

95 Davidson B. Analysis of SUTL business. 12 Dec 1991. British American Tobacco. Bates No. 300028602. Available from Guildford Depository.

96 Davidson BC. Minutes of an 01 March 1991 meeting between BATUKE and SUTL. 6 March 1991. British American Tobacco. Bates No. 300028662/ 8678. Available from Guildford Depository. 
97 Duncan R. Notes of BAT Meeting with SUTL in Singapore, 24.2.93. 1993. British American Tobacco. Bates No. 500045568 Available from Guildford Depository.

98 Barnes MR. JPGL Multi-Country Research. 6 Sep 1993. British American Tobacco. Bates No. 500284545. Available from Guildford Depository.

99 Duncan R. [Bangladesh Tobacco Company Fax to Tim Wilson]. nd (Received stamp 4 January 1991). British American Tobacco. Bates No. 503914292 Available from Guildford Depository.

100 Duncan RMH. BTC Monthly Review for December 1991. 12 Jan 1992. British American Tobacco. Bates No. 500081403/1406. Available from Guildford Depository.

101 BATUKE Export Markets Operating Group. Meeting Minutes. 7 Jul 1987. British American Tobacco. Bates No. 301654793 Available from Guildford Depository.

102 O'Keeffe PC. Export Channel Management. 8 Aug 1994. British American Tobacco. Bates No. 503932264-2272. Available from Guildford Depository.

103 Maguire K, Campbell D. Tobacco giant implicated in global smuggling schemes. The Guardian Monday, 31 January $2000 \mathrm{http}: / /$ www.guardian.co.uk/bat/article/0,2763,191293,00.html.

104 BAT Bates No. 500299321.

105 Greig C. [BAT Letter to Malcolm Fry, Norman Davis]. 26 May 1993. British American Tobacco. Bates No. 400657565. Available from Guildford Depository.

106 Indian Sub Continent Market Status Report April/May 1994. British American Tobacco. Bates No. 503964737. Available from Guildford Depository.

107 Bates T. SE 555 in Bangladesh. 25 Feb 1992. British American Tobacco. Bates No. 500030590. Available from Guildford Depository.

108 Desai N. India Domestic Markets. 31 Mar 1994. British American Tobacco. Bates No. 503964664. Available from Guildford Depository.

109 BAT. BATCo. ASIA/PACIFIC REVIEW (SECRET). May 1993. British American Tobacco. Bates No. 500045965/6049. Available from Guildford Depository.
110 Combe F. [BAT Fax to Paul Adams, BATCo Staines]. 19 Jan 1994. British American Tobacco. Bates No.500046091. Available from Guildford Depository.

111 Combe F. Minutes of SUTL Meeting 24th march 1993. British American Tobacco. Bates No. 500045571/5575. Available from Guildford Depository.

112 Adams P. Getting it right in the fight against fakes. Speech to the Global Congress on Combating Counterfeiting, World Customs Organisation Headquarters, Brussels, 25 May 2004. http://www.bat.com/oneweb/ sites/uk_3mnfen.nsf/vwPagesWebLive/DO53BUBT/ [Accessed 12 Jul 2004].

113 Kwok J. [Message from M.T.C. 15.10.85] 15 Oct 1985. British American Tobacco. Bates No. 301666513. Available from Guildford Depository.

114 Coburn R. [File note re: telephone conversation with Gnanalingham, MTC] 24 Oct 1985. British American Tobacco. Bates No. 310666510/6512. Available from Guildford Depository.

115 Trairatanobhas V. Re: Transit Market Survey. 13 Feb 1992. British American Tobacco. Bates No. 400728276/8279. Available from Guildford Depository.

116 Department of Trade and Industry. Press Release - British American Tobacco. P/2004/118. 26 March 2004 http://www.gnn.gov.uk/environment/ detail.asp? ReleaselD $=112695 \&$ NewsArealD $=2 \&$ NavigatedFrom Department [Accessed 24 Jun 2004].

117 European Commission. European Commission and Philip Morris International sign 12-year Agreement to combat contraband and counterfeit cigarettes. IP/04/882, 9 Jul 2004, http://europa.eu.int/rapid/ pressReleasesAction.do? reference $=\mathrm{IP} / 04 / 882$ \&type $=$ HTML\&aged $=0$ \&language $=E N \&$ guilanguage $=$ en [Accessed 16 Jul 2004) .

118 Framework Convention Alliance. The Framework Convention on Tobacco Control http://fctc.org/about_FCTC/index.shtml.

119 United States. Department of Justice. Bureau of Alcohol, Tobacco, Firearms and Explosives. International Conference on Illicit Tobacco Trade (ICITT) http://www.aff.gov/tobacco/icitt/fctc.htm. 